\title{
STUDI KEMAMPUAN MOTORIK SISWA SEKOLAH DASAR NEGERI 28 AIR TAWAR TIMUR KECAMATAN PADANG UTARA KOTA PADANG
}

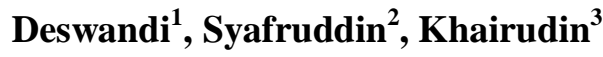 \\ ${ }^{1}$ Program Studi Pendidikan Jasmani Kesehatan dan Rekreasi, Fakultas Ilmu Keolahragaan, \\ Universitas Negeri Padang. Jalan Prof. Dr. Hamka Air Tawar Barat, Padang, 25132, Indonesia. \\ ${ }^{2}$ Program Studi Ilmu Keolahragaan, Fakultas Ilmu Keolahragaan, Universitas Negeri Padang. Jalan \\ Prof. Dr. Hamka Air Tawar Barat, Padang, 25132, Indonesia. \\ ${ }^{3}$ Program Studi Ilmu Keolahragaan, Fakultas Ilmu Keolahragaan, Universitas Negeri Padang. Jalan \\ Prof. Dr. Hamka Air Tawar Barat, Padang, 25132, Indonesia.
}

E-mail: deswandi@fik.unp.ac.id ${ }^{1}, \underline{\text { syafruddin@fik.unp.ac.id }}{ }^{2}, \underline{\text { khairudin @ fik.unp.ac.id }^{3}}$

\begin{abstract}
Abstrak
Masalah dalam penelitian ini adalah pelaksanaan pembelajaran Penjasorkes di SD Negeri 28 Air Tawar Timur Kecamatan Padang Utara Kota Padang belum berjalan sebagaimana yang diharapkan. Banyak faktor yang menyebabkannya, salah satu faktor penulis duga disebabkan oleh kemampuan motorik. Tujuan dari penelitian ini adalah untuk mengetahui kemampuan motorik siswa SD Negeri 28 Air Tawar Timur Kecamatan Padang Utara Kota Padang

Jenis Penelitian ini adalah deskriptif. Populasi dalam penelitian ini adalah seluruh siswa kelas V SD Negeri 28 Air Tawar Timur Kecamatan Padang Utara Kota Padang yang berjumlah 35 orang, Penarikan Sampel menggunakan teknik total sampling, yaitu menetapkan siswa kelas V sebagai sampel yang berjumlah 35 orang, dimana siswa putra 16 orang dan siswa putri 19 orang. Data dikumpulkan dengan menggunakan pengukuran tes kemampuan motorik yang meliputi: Lempar bola basket. tes koordinasi mata tangan, lari 40 meter, Tes lompat jauh tanpa awalan. Data dianalisis dengan menggunakan teknik persentase

Dari analisis data diperoleh hasil penelitian sebagai berikut: 1) Dari 16 orang responden putra menunjukkan bahwa kemampuan motorik pada kategori sangat baik 6 orang, baik 10 orang sedangkan kategori sedang, kurang dan sangat kurang tidak ada. Rata - rata skor kemampuan motorik siswa putra 13.38, termasuk kategori baik, 2) Dari 19 orang responden putri menunjukkan bahwa kemampuan motorik pada kategori sangat baik 4 orang, baik 11 orang, sedang 4 orang sedangkan kategori kurang dan sangat kurang tidak ada. Rata - rata skor kemampuan motorik siswa putri 12.58 , termasuk kategori baik.
\end{abstract}

\section{Kata Kunci: Kemampuan Motorik, Motorik Siswa}

\section{PENDAHULUAN}

Sekolah Dasar merupakan salah satu lembaga pendidikan yang memberikan bekal kepada siswa untuk melanjutkan pendidikannya ke jenjang yang lebih tinggi. Mata pelajaran yang tercantum dalam kurikulum SD dapat dikelompokkan: Program pendidikan umum, program pendidikan, akademis, dan program pendidikan keterampilan. Diantara mata pelajaran program pendidikan umum adalah mata pelajaran Pendidikan Jasmani, Olahraga, Dan Kesehatan (Penjasorkes).

Luthan (2002:5) mengatakan bahwa : "Pendidikan Jasmani adalah proses pendidikan melalui aktivitas jasmani, permainan dan atau olahraga". Dengan demikian maka dapat disimpulkan bahwa pendidikan jasmani merupakan serangkaian aktivitas jasmani atau olahraga, bisa dalam bentuk permainan atau mungkin juga salah satu dari cabang olahraga.

Tujuan Pendidikan Jasmani di Sekolah Dasar menurut Depdiknas (2003:3) adalah "untuk membantu siswa dalam mengembangkan dan meningkatkan kebugaran jasmani (physical fitness) yang dalam proses pembelajarannya mengutamakan aktivitas jasmani dan pembinaan pola hidup sehat".

Bila tujuan dan fungsi Penjasorkes sudah tercapai, tentu pengetahuan, keterampilan, sikap, dan kebugaran jasmani serta kemampuan motorik (motor ability) siswa menjadi lebih baik, karena siswa kaya dengan pengetahuan gerak 
yang banyak. Menurut Kirkendal dalam Mutohir (2004:75) mengatakan bahwa :

"Kemampuan motorik merupakan kualitas kemampuan seseorang yang dapat mempermudah dalam melakukan keterampilan gerak". Lebih lanjut dikatakan bahwa kemampuan motorik itulah yang kemudian berperan sebagai landasan bagi perkembangan keterampilan. Artinya pada anak Sekolah Dasar kemampuan motorik adalah salah satu aspek penting dalam pembelajaran pendidikan jasmani. Karena kemampuan motorik adalah salah satu tujuan dan fungsionalisasi potensi yang dimiliki siswa yang diperoleh dari pembelajaran pendidikan jasmani di sekolah dasar".

Berdasarkan kutipan di atas jelas bahwa salah satu indikator tercapai tidaknya tujuan dalam pembelajaran pendidikan jasmani di Sekolah Dasar tersebut dapat dilihat tingkat kemampuan motorik siswa. Kemampuan motorik dapat ditingkatkan melalui aktivitas bermain, semakin banyak gerak anak dalam aktivitas bermain maka semakin baik kemampuan motoriknya.

Untuk mencapai fungsi dan tujuan pembelajaran Penjasorkes di Sekolah Dasar, pelaksanaan pembelajaran hendaknya mendorong guru lebih siap untuk melakukan kegiatan pembelajaran dengan perencanaan yang matang dan mampu melaksanaan proses pembelajaran dengan baik.

Pelaksanaan pembelajaran harus disusun secara sistematis, utuh dan menyeluruh. Dalam hal ini materi yang dikembangakan dan disajikan sesuai dengan kebutuhan dan kemampuan peserta didik, sesuai dengan kondisi dan kebutuhan lingkungan sekolah dan daerah.

Pelaksanaan pembelajaran pendidikan jasmani olahraga dan kesehatan di Sekolah Dasar, diharapkan dapat terlaksana dengan baik, sehingga peserta didik memperoleh pengetahuan, berbagai keterampilan dan merangsang pertumbuhan dan perkembangan gerak peserta didik, penalaran, penghayatan nilai-nilai seperti sikap mental, emosionalspiritual-sosial, serta pembiasaan pola hidup sehat yang berguna bagi kehidupannya.

Salah satu prinsip penting dalam keberhasilan pelaksanaan pembelajaran pendidikan jasmani olahraga dan kesehatan adalah partisipasi peserta didik secara penuh dalam mengikuti proses pembelajaran atau peserta didik terlibat aktif disetiap pembelajaran yang diberikan guru. Dalam arti lain kesiapan siswa dalam menghadapi proses pembelajaran Penjasorkes merupakan suatu keharusan untuk ditumbuhkan, sehingga pembelajaran menjadi suatu kesenangan.

Di samping itu pelaksanaan pembelajaran penjasorkes dapat dilaksanakan dengan baik banyak faktor yang mempengaruhinya, seperti kesegaran jasmani, kemampuan dan kreaktifitasan guru dalam mengajar, sarana dan prasarana yang dibutuhkan, minat, intelegensi, pemilihan metode dan media pembelajaran yang tepat, motivasi siswa dalam belajar, lingkungan belajar yang kondusif, status gizi, kemampuan motorik, dan lain-lain sebagainya.

Berdasarkan observasi dan penulis di lapangan terhadap pelaksanaan pembelajaran pendidikan jasmani olahraga dan kesehatan di SD Negeri 28 Air Tawar Timur Kecamatan Padang Utara Kota Padang, terlihat dari penampilan dan sikap siswa dalam mengikuti pembelajaran banyak siswa yang santai, ada yang malas melakukan gerakan yang diajarkan guru, mereka cepat lelah dan terkesan mereka kurang mau bergerak.

Sehingga penulis beranggapan pelaksanaan Penjasorkes belum terlaksana dengan baik sebagaimana mestinya, peneliti menduga bahwa hal ini disebabkan oleh kemampuan motorik siswa masih rendah. Banyak faktor yang mempengaruhi kemampuan motorik siswa, diantaranya kurangnya unsur kekuatan otot lengan, kecepatan, keseimbangan, koordinasi dan kekuatan otot tungkai yang dimiliki siswa.

Dengan demikian, untuk mendapatkan data dan informasi yang mendekati kebenaran ilmiah mengenai kemampuan motorik siswa SD Negeri 28 Air Tawar Timur Kecamatan Padang Utara Kota Padang, maka peneliti tertarik untuk melakukan suatu penelitian.

Kemampuan dapat diartikan sebagai kecakapan dan kesanggupak siswa dalam melakukan suatu gerak (motorik). Kemampuan motorik ini penting dimiliki siswa Sekolah Dasar, terutama dalam mengikuti semua aktivitas gerak yang terdapat dalam proses pembelajaran, khususnya dalam mata pelajaran pendidikan jasmani, olahraga dan kesehatan.

Kemampuan motorik adalah kecakapan, kekuatan dan kesanggupan melakukan sesuatu 
Depdikbud dalam Gusril (2008:10). Mutohir (2004:75) mengartikan kemampuan motorik adalah "kualitas kemampuan seseorang yang dapat mempermudah dalam melakukan keterampilan gerak".

Sedangkan kemampuan motorik menurut Luthan dalam Mutohir (2004:75) adalah "merupakan kualitas umum yang dapat ditingkatkan melalui latihan. Dengan demikian kemampuan motorik dapat diartikan kualitas kemampuan seseorang (individu) dalam melakukan gerakan yang dipandang sebagai landasan keberhasilan untuk menyelesaikan keterampilan gerak.

Kemampuan motorik orang berbedabeda satu sama lain dan tergantung kepada banyaknya pengalaman gerakan yang dikuasai. Menurut Magill dalam Mutohir (2004:76) mengatakan bahwa "kemampuan motorik dapat ditinjau dari dua aspek, yaitu kemampuan persepsi motorik (perceptual motor ability), dan kemampuan ketangkasan fisik (physical profiency abilities)".

Dalam kemampuan persepsi motorik terdapat dua komponen yaitu proses pengamatan (persepsi) dan saling berinteraksi satu sama lainnya. Artinya semua gerakan yang dillakukan oleh anak-anak dipengaruhi oleh persepsi motoriknya terhadap rangsangan yang datang. Persepsi motorik menunjukan kepada kemampuan individu untuk menerima, menginterprestasikan, dan memberikan respon yang tepat kepada stimulus yang datang kepadanya.

Dari uraian di atas, maka dapat dicontohkan pada seorang anak yang sedang melakukan pukulan dalam permainan kasti di sekolah. Perhatian utama yang dilakukan siswa antara lain adalah posisi berdiri, cara memegang alat pemukul, arah bola sewaktu dilempar oleh pelempar, dan arah bola akan dipukul agar tidak dapat ditangkap lawan.

Selanjutnya anak juga akan berfikir perkenaan bola, tingginya bola akan dipantulkan dan posisi lawan, serta lain-lain sebagainya. Semua itu adalah merupakan stimulus lingkungan yang harus diperhatikan oleh siswa dalam melakukan pukulan dalam permainan kasti, seperti yang dilihat, dirasakan, diperhatikan, didengar dan dirasakan.

Dengan demikian dapat dikatakan bahwa kemampuan motorik penting artinya untuk dimiliki oleh siswa. Artinya kemampuan/ kesanggupan individu dalam melakukan berbagai macam gerak (motorik) atau kelincahan/ keterampilan dari bagian tubuh individu itu sendiri beserta koordinasi kerja bagian organ tubuh individu sebagai penunjang kualitas dari gerak individu yang tidak terbatas, dari setiap dimensi dalam program suatu tugas yang mungkin sudah dikenal sebelumnya atau baru sama sekali.

Kemampuan motorik seseorang dapat meningkat tergantung kepada banyaknya pengalaman anak yang dikuasainya. Oleh sebab itu pentingnya pendidikan Jasmani, kesehatan di sekolah guna untuk memperluas dan memperbanyak pengalaman $\sim \cdots 1$ termasuk aktiviats bermain yang dibs 8 ,leh guru Penjasorkes di sekolah, in dapat menunjang pertumbuhan, perkembangan dari kemampuan motorik individu.

Hal ini dapat diperoleh siswa pada saat mengikuti pembelajaran pendidikan jasmani di sekolah. Pada kenyataannya pendidikan jasmani dan kesehatan adalah suatu bidang kajian yang sungguh luas. Titik perhatiannya adalah peningkatakan gerak manusia. Lebih khususnya lagi, penjas berkaitan dengan hubungan antara gerak manusia dan wilayah pendidikan lainnya, hubungan dari perkembangan tubuh, fisik dengan pikiran dan jiwanya.

Tahap atau fase belajar motorik adalah suatu fase yang menggambarkan keadaan penguasaan keterampilan motorik seseorang dalam melaksanakan gerakan-gerakan olahraga, kemampuan seseorang untuk dapat menguasai keterampilan-keterampilan motorik olahraga berbeda-beda.

Pada anak-anak usia sekolah dasar pada umumnya memiliki pengalaman-pengalaman gerakan. pengalaman gerakan yang mereka miliki pada umumnya pengalaman gerakan yang mereka peroleh dari berbagai aksi motorik yang mereka lakukan dari kehidupan sehari-hari, sehingga variasi pengalaman gerakan yang mereka miliki terbatas pada variasi-variasi yang mereka lakukan sehari-hari. Misalnya berjalan, berlari, melompat, melempar, memanjat, berguling dan sebagainya. Tetapi belum lagi terarah pada suatu cabang olahraga tertentu, walaupun pengalaman gerakan yang mereka miliki tersebut akan membantu mempermudah penguasaan keterampilan motorik olahraga.

Didalam pembentukan, pembinaan dan pengembangan keterampilan motorik olahraga pada anak-anak usia sekolah dasar harus dikelola dengan baik karena pada usia tersebut 
merupakan fase yang menentukan bagi perkembangan keterampilan motorik mereka dalam suatu cabang olahraga tertentu. dalam hal ini guru pendidikan jasmani sekolah dasar perlu memahami setiap ciri-ciri koordinasi gerakan yang merupakan faktor yang sangat menentukan keberhasilan seseorang dalam penguasaan keterampilan motorik dalam olahraga.

Kiram (2000:23) mengemukakan kemampuan seseorang untuk dapat menguasai keterampilan-keterampilan motorik olahraga berbeda-beda, perbedaan tersebut ditentukan oleh " kemampuan kondisi dan koordinasi yang dimiliki, perbedaan usia, pengalaman gerakan, jenis kelamin, frekuensi latihan, perbedaan tujuan dan motivasi dalam mempelajari suatu keterampilan motorik serta perbedaan suatu kemampuan kognitif".

Berkembangnya kemampuan motorik sanagat ditentukan oleh dua faktor pertumbuhan dan perkembangan, kedua faktor ini masih harus didukung oleh latihan sesuai dengan kematangan anak dan gizi yang baik. Pertumbuhan yang dimaksud disini adalah perubahan kuantitatif dari organ organ tubuh yag dapat diukur dalam panjang $(\mathrm{cm}=$ sentimeter $)$, dalam berat $(\mathrm{kg}=$ kilogram) atau dalam ukuran isi sedangkan perkembangan merupakan proses menuju kearah yang leih baik, dalam arti lain merupakan perubahan kualitatif misalnya berkaitan dengan kepribadian, psikis dan perubahan fungsi otot menjadi leih baik.

Disamping itu dapat melatih anak untuk belajar sopan santun, bersosialisasi dengan teman sebaya dan bisa memperbaiki kebugaran fisik serta kemampuan jasmani akan menjadi lebih baik. namun ada kemungkinan bahwa salah satu perkembangan motoriknya adalah prinsip kontinuitas.

Sukintaka (2004:80-90) mengelompokan tahap-tahap kemampuan motorik siswa kelas $\mathrm{V}$ dan VI (umur 10-12 tahun) sekolah dasar sebagai berikut : 1) Aktivitas rekreasi, 2) Aquatik, 3) Permainan olahraga, 4) Aktivitas ritmik, 5). aktivitas pengembangan, 6) tes terhadap diri sendiri.

Belajar motorik (gerak) menurut Kiram (2000:15) adalah suatu proses perbaikan kemampuan koordinasi motorik, melalui optimalisasi faktor-faktor persyaratan luar dan dalam yang bertujuan untuk menguasai keterampilan, kemampuan dan tingkah tertentu". Dengan demikian dapat diartikan bahwa seorang anak Sekolah Dasar belajar gerak seperti bermain sepakbola, berm sebagainya, maka hal ini proses perbaikan kemaml 11 isti, dan ran suatu koordinasi motorik.

Unsur-unsur yang terkandung dalam kemampuan motorik menurut Harsono (1988:155) adalah "kekuatan, kecepatan, keseimbangan, kelincahan, daya tahan dan koordinasi gerakan". Artinya ada sebanyak enam unsur kemampuan motorik yang dapat dikembangkan,bagi anak-anak meningkatkan kemampuan motorik dapat diperoleh dari kebiasaan untuk melakukan aktifitas yang berhubungan dengan penampilan fisik, seperti aktivitas bermain.

Adapun unsur kemampuan motorik yang diperoleh dari aktivitas bermain yang dilakukan anak-anak seperti bermain olahraga sepakbola, bermain bolavoli, kasti, main kejar-kejaran dan sebagainya. Dengan bermain anak-anak menjadi kuat ototnya, kecepatan bertambah, koordinasi gerakan semakin baik, keseimbangan, gerakannya semakin lincah dan gesit. Artinya aktivitas bermain dapat meningkatkan kemampuan motorik anak.

Sedangkan menurut Mutohir (2004:79) Adapun unsur-unsur kemampuan motorik yaitu: " Kekuatan, koordinasi, kecepatan, keseimbangan dan kelincahan yang dapat dikembangkan secara penuh melalui program latihan".

a) Kekuatan adalah kemampuan sekelompok otot untuk menimbulkan tenaga sewaktu reaksi. Kekuatan otot harus dipunyai oleh anak. Apabila anak tidak mempunyai kekuatan otot tentu dia tidak dapat melakukan aktivitas bermain yang menggunakan fisik

b) Koordinasi kemampuan untuk mempersatukan atau memisahkan dalam suatu tugas kerja yang kompleks.dengan ketentua bahwa gerakan bahwa gerakan koordinasi meliputi kesempurnaan waktu antara otot dan sistem syaraf (Mutohir, 2004:80). Sebagai contoh: anak dalam melekukan lemparan harus ada koordinasi seluruh anggota tubuh yang terlibat. Anak dikatakan baik koordinasi gerakannya apabila ia mampu bergerak dengan mudah, lancar dalam gerakan dan irama gerakannya terkontrol dengan baik. Waharsono dan sajoto dalam Mutohir (2004:80) menyatakan "kemampuan koordinasi gerakan secara 
umum anak laki-laki dan perempuan tidak berbeda sampai umur 11 tahun. Tetapi bila dibandingkan dalam beberapa aspek kemampuan tertentu bisa dijumpai ada perbedaan".

c) Kecepatan adalah sebagai kemampuan yang berdasarkan kelentukan dalam satuan waktu tertentu.

d) Keseimbangan adalah kemampuan seseorang untuk mempertahankan tubuh dalam berbagai posisi

e) Kelincahan adalah kemampuan seseorang mengubah arah dan posisi tubuh dengan cepat dan tepat pada waktu bergerak dari satu titik ketitik lain.misalnya:siswa melakukan lari zigzag dan sedemikian cepat waktu yang ditempuh, maka semakin tinggi kelincahan.

Menurut Gusril (2008:17) Kemampuan motorik dipengaruhi oleh faktor mekanik dan faktor fisik sebagai berikut :

"Faktor mekanik meliputi " a) faktor kesimbangan yang terdiri dari dari pusat gaya, garis gaya dan dasar penyokong, b) faktor pemberi gaya yang terdiri dari gerak yang lambat, percepatan, aktivitas/rekreasi, c) faktor penerima gaya yang terdiri dari:' Fase refleks, fase belum sempurna, fase dasar, e) kemampuan manipulatif, f) kemampuan yang stabil". Faktor fisik terdapat unsur-unsur sebagai berikut " a) faktor kesegaran jasmani yang terdiri dari kekuatan, daya tahan aerobik, kelentukan dan posisi tubuh, b) faktor kesegaran gerak (motor Fitnesh) terdiri dari kecepatan, kelincahan, koordinasi, keseimbangan dan daya ledak".

Berdasarkan uraian di atas jelas untuk meningkatkan unsur kemampuan motorik seperti kekuatan, keseimbangan, kecepatan, kelincahan dan koordinasi gerakan dapat ditingkatkan melalui latihan-latihan olahraga, melalui berbagai aktivitas bermain yang memang banyak disenangi dan disukai anak, khususnya anakanak seusia Sekolah Dasar.

Begitu juga halnya dengan anak-anak SD Negeri 28 Air Tawar Timur Kecamatan Padang Utara Kota Padang. Selanjutnya Keterampilan motorik tidak akan berkembang melalui kematangan saja, melainkan keterampilan motorik tersebut harus dipelajari. Sehingga keterampilan motorik anak yang dipelajar dapat meningkatkan kualitas keterampilan motorik.
Masa kecil sering dikatakan saat ideal untuk mempelajari keterampilan motorik, karena berkembangnya kemampuan motorik sangat ditentukan oleh dua faktor yaitu: pertumbuhan dan perkembangan. Dari kedua faktor ini masih didukung dengan latihan sesuai dengan kematangan anak, dan gizi yang baik.

Faktor-faktor yang mempengaruhi perkembangan kemampuan motorik anak (siswa) meliputi dua faktor yaitu: faktor internal dan faktor eksternal. Pengaruh yang diterima oleh anak, diawali sejak anak masih dalam kandungan ibunya. Oleh karenanya, kondisi ibu pada saat mengandung akan sangat berpengaruh terhadap perkembangan kemampuan motorik bayi (janin) yang sedang dikandung.

Banyak faktor yang mempengaruhi kemampuan motorik seseorang diantaranya :seperti yang dikemukakan Gusril (2003:9) yaitu "kesegaran jasmani, aktivitas bermain dan status gizi”.Menurut Sukintaka (2004:47) mengemukakan bahwa berkembangnya kemampuan motorik sangat ditentukan oleh dua faktor yaitu: "faktor pertumbuhan dan faktor perkembangan".

Dari dua faktor penentu ini masih harus didukung dengan latihan, yang sesuai dengan kematangan anak dan gizi yang baik. Status gizi adalah keadaan tubuh sebagai akibat konsumsi makanan dan penggunaan zat-zat gizi. Makanan adalah bahan selain obat yang mengandung zatzat gizi dan atau unsur-unsur/ikatan kimia yang dapat diubah menjadi zat gizi oleh tubuh, yang berguna bila dimasukkan ke dalam tubuh.

Makanan yang bergizi diperlukan untuk kesehatan tubuh yaitu: untuk menyediakan energi, membangun, dan memelihara jaringan tubuh, serta mengatur proses-proses kehidpan dalam tubuh. Sekarang kata gizi mempunyai pengertian lebih luas, di samping untuk kesehatan, gizi dikaitkan dengan potensi ekonomi seseorang, karena gizi berkaitan dengan perkembangan otak, kemampuan belajar, dan produktivitas.

Mutohir dkk (2004:82) menyatakan "fungsi utama kemampuan motorik adalah untuk mengembangkan kesanggupan dan kemampuan setiap individu yang berguna untuk mempertinggi daya kerja". Dengan mempunyai kemampuan motorik yang baik, tentu individu mempunyai landasan untuk menguasai tugas keterampilan motorik yang khusus.

Semua unsur-unsur kemampuan motorik pada siswa Sekolah Dasar dapat berkembang 
melalui kegiatan pendidikan jasmani dan aktifitas bermain yang melibatkan otot.Semakin banyak siswa mengalami aktivitas gerak tentu unsur-unsur kemampuan motorik semakin terlatih.

Pengalaman ini di simpan dalam ingatan untuk dipergunakan pada keempatan lain, jika melakukan gerakan yang sama. Dengan banyaknya pengalaman motorik yang dilakukan oleh siswa SD tentu akan menambah kematangannya dalam melakukan aktivitas motorik. Di samping itu menurut Mutohir (2004:7) terminologi perkembangan motorik "ada dua konsep dasar yaitu pertumbuhan dan perkembangan.

Pertumbuhan berarti kenaikan kuantitatif dalam ukuran. Kemudian pertumbuhan lebih ditekankan pada bertambahnya ukuran fisik dan bukan pertumbuhan social atau kesadaran". Dengan demikian dapat diartikan bahwa dengan kemampuan motorik baik, dapat meningkatkan pertumbuhan fisik anak.

Sedangkan perkembangan dapat terjadi dalam bentuk perubahan kuantitatif/kualitatif atau kedua-duanya secara serempak. Perkembangan motori merupakan suatu proses yang berkesinambungan dan berurutan dimana kemajuan individu dari gerak yang sederhana dan belum terorganisir secara baik dalam keterampilan yang komplek, seperti sekelompok anak-anak laki bermain sepakbola.

Dari penjelasan di atas, maka jelaslah bahwa fungsi kemampuan motorik dapat meningkatkan pertumbuhan dan perkembangan fisik. Di samping itu anak-anak kaya dengan gerak dan secara otomatis unsur-unsur kemampuan motorik seperti kekuatan, daya tahan, kecepatan, kelincahan dan koordinasi gerakan semakin baik. Hal ini dapat membuat siswa semakin sehat jasmaninya atau tingkat kesegaran jasmaninya menjadi lebih baik

Semakin banyak siswa mengalami aktivitas gerak tentu unsur-unsur kemampuan motorik semakin terlatih. Pengalaman ini di simpan dalam ingatan untuk di pergunakan pada kesempatan lain, jika melakukan gerakan yang sama.

Dengan banyaknya pengalaman motorik yang di lakukan oleh siswa SD tentu akan menambah kematanganya dalam melakukan aktifitas motorik. Kiram dalam Mutohir (2004:83) menyatakan ada tiga dorongan yang timbul bagi anak berusia 6-12 tahun dalam pengembangan tugas-tugasnya : “a) Dorongan dari lingkungan rumah ke kelompok sejawat (peer group), b) Dorongan pada realisasi kerja dan suasana bermain yang masing-masing memerlukan neuromuskuler, c) Dorongan kedalam konsep dunia dewasa yang memerlukan peningkatan keterampilan, seni berlogika dan berkomunikasi.

\section{METODE}

Penelitian ini adalah penelitian deskriptif yang bertujuan untuk menggambarkan dan menafsirkan data sebagaimana adanya. Menurut Arikunto (2002:30) "penelitian deskriptif adalah penelitian yang tidak bermaksud untuk menguji hipotesis tertentu, tetapi hanya menggambarkan apa adanya suatu variabel, gejala keadaan".

Dengan demikian dapat diartikan bahwa penelitian deskriptif adalah suatu bentuk penelitian yang digunakan untuk melihat, mengetahui, dan mengungkapkan data atau keadaan sebagaimana adanya. Dalam penelitian ini akan mengungkapkan data yang ditemui di lapangan yaitu tentang kemampuan motorik siswa SD Negeri 28 Air Tawar Timur Kecamatan Padang Utara Kota Padang.

Penelitian ini dilakukan di Sekolah Dasar Negeri 28 Air Tawar Timur Kecamatan Padang Utara Kota Padang. Sedangkan waktu penelitian ini dilaksanakan bulan Desember 2013.

Menurut Arikunto (2002 : 108) yaitu "Populasi adalah keseluruhan subjek penelitian. Populasi dalam penelitian ini adalah seluruh siswa kelas V SD Negeri 28 Air Tawar Timur Kecamatan Padang Utara Kota Padang yang dengan jumlah 35 orang. Untuk lebih jelasnya dapat dilihat pada tabel dibawah ini:

\section{Tabel 1. Populasi Penelitian}

\begin{tabular}{|c|c|c|c|}
\hline \multirow{2}{*}{ Kelas } & $\begin{array}{c}\text { Jenis } \\
\text { Kelamin }\end{array}$ & Jumlah & \multicolumn{1}{|c|}{} \\
\cline { 2 - 3 } & Putera & Puteri & \\
\hline V & 16 & 19 & 35 \\
\hline
\end{tabular}

Sumber. TU SD Negeri 28 Air Tawar Timur Kota Padang

Menurut Arikunto, (2002:109) Sampel adalah : "sebagian dari populasi sebagai subjek dari penelitian". Sampel dalam penelitian ini diambil dengan menggunakan teknik total sampling. Dimana seluruh populasi dijadikan sampel. Dengan demikian jumlah sampel dalam penelitian ini berjumlah sebanyak 35 orang siswa putra dan putri kelas V SD Negeri 28 Air Tawar Kota Padang.

Dalam penelitian ini jenis data yang diperlukan adalah data primer dan data sekunder. 
Data primer adalah data yang diambil langsung oleh peneliti dari tes dan pengukuran kemampuan motorik terhadap siswa yang terpilih menjadi sampel.

Sedangkan sumber data dalam hasil penelitian ini adalah siswa Sekolah Dasar Negeri 28 Air Tawar Timur Kecamatan Padang Utara Kota Padang yang terpilih menjadi sampel.

\section{A. Teknik Pengumpulan Data}

Menurut Gusril, (2008:202), Tes kemampuan motorik terdiri dari : (1) Lempar Bola Basket (Basket Ball Throw); (2) Lari 40 meter; (3) Passing Bola ke Dinding (Wall Pass); (4) Lompat Jauh Tanpa Awalan (Broad Jump). Tujuan untuk mengukur kemampuan motorik umum yang dipunyai oleh siswa dan sekaligus untuk mengelompokkan siswa dalam kelas. Untuk jelasnya dapat diuraikan dibawah ini.

\section{Lempar Bola Basket (Basketball Throw)}

a. Tujuan. Tes ini bertujuan untuk mengukur kekuatan lengan, bahu, dan koordinasi.

b. Alat dan fasilitas.

1) Lintasan datar, tidak licin, 2) Meteran, 3) Pluit, 4) Bola Basket, 5) Alat Tulis

c. Petugas Tes

1) Pengamat garis batas lemparan, 2)

d. Pelaksanaan Pengukur jarak, 3) Pencatat hasil

1) Siswa mengambil tempat di belakang garis lemparan dengan siap memegang bola. Tanpa awalan lari (step) melempar bola dengan satu tangan sejauh mungkin. Jarak lemparan di ukur dari jauhnya bagian dalam sampai ke garis lemparan dan di catat. Percobaan di lakukan tiga kali dan lemparan yang terjauh di catat sebagai hasil lemparan. Pelaksana melempar bola dengan ayunan sejauh-jauhnya kebelakang beberapa kali, tetapi tidak boleh melakukan awalan lari atau melangkah. Sewaktu melempar tidak boleh menginjak garis batas lemparan. Bola basket yang di pakai adalah bola nomor 3 dengan berat $600-625$ gr.

2) Jarak lempar diukur dari jauhnya bagian dalam sampai kegaris batas lemparan.
3) Percobaan dilakukan tiga kali dan lemparan yang terjauh dicatat sebagai hasil lemparan. Untuk lebih jelasnya dapat dilihat pada gambar di bawah ini:

22

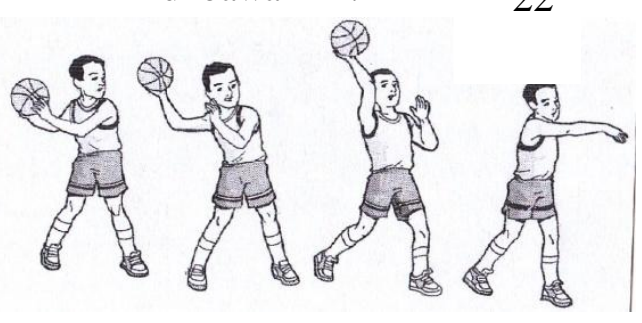

Gambar 2. Lempar Bola Basket

Sumber : Muhajir, 2006:14

\section{Lari 40 Meter}

1) Tujuan

Tes ini bertujuan untuk mengukur kecepatan.

2) Alat dan fasilitas

a) Lintasan lurus, datar, tidak licin, berjarak 40 meter

b) Bendera star

c) Pluit

d) Tiang pancang

e) Stopwatch

f) Serbuk kapur

g) Alat tulis 3)

4) Pelaksanaan

a. Sikap permulaan

Sikap star dilakukan dengan star berdiri aba-aba "bersedia" peserta tes sudah dan siap dibelakang garis star.

b. Gerakan

1. Pada aba-aba "SIAP" peserta mengambil sikap star berdiri

2. Pada aba - aba "YA" peserta lari secepat mungkin menuju garis finish, menempuh jarak 40 meter

3. Lari bisa diulang apabila

1) Pelari mencuri star

2) Pelari tidak melewati garis finish

3) Pelari terganggu dengan pelari lain

4) Jatuh / terpeleset

c. Pengukuran waktu

Pengukuran waktu dilakukan dari saat bendera diangkat sampai pelari melintasi garis finish.

d. Pencatat Hasil 
(1) Hasil yang dicatat adalah waktu yang dicapai oleh pelari untuk menempuh jarak 40 meter dalam satuan waktu detik

(2) Waktu dicatat satu angka dibelakang koma

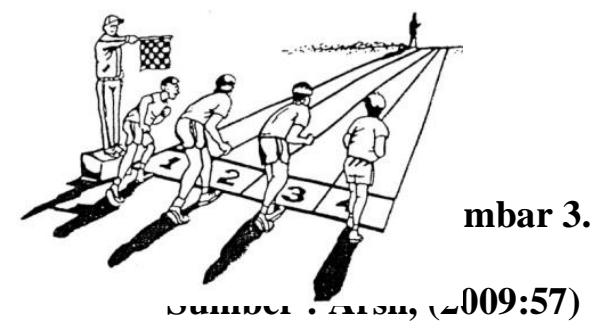

\section{Passing bola ke dinding (wall pass)}

a. Tujuan. Tes ini bertujuan untuk mengukur koordinasi mata dan tangan.

b. Alat dan fasilitas

1) Bola Voly, 2) Meteran, 3) Pluit, 4) Stop Wacth, 5) Alat Tulis

c. Petugas Tes

1) Pengamat waktu, 2) Pengamat gerakan, 3) Pencatat hasil

d. Pelaksanaan

1) Siswa berdiri di belakang garis pembatas yang jaraknya $2 \mathrm{~m}$ dari dinding. Pada aba-aba mulai siswa mempassing bola ke dinding. Siswa melakukan passing bola ke dinding sebanyak mungkin selama 15 detik. Jika siswa lepas kontrol bolanya, siswa harus mengambil bola yang lepas kontrol bola tadi dengan cepat dan kembali berdiri di belakang garis pembatas dan memantulkan bola kembali sampai batas waktu 15 detik. Bola voly yang di pakai adalah bola nomor 3 dengan berat 300-325 gr.

2) Lemparan yang dihitung adalah lemparan yang dianggap sah, yaitu lemparan dengan kedua kaki siswa tetap berada di belakang garis pembatas lemparan.

3) Jumlah lemparan yang dianggap sah dalam kurun waktu 15 detik dicatat sebagai hasil lemparan. Untuk lebih jelasnya dapat dilihat pada gambar di bawah ini:

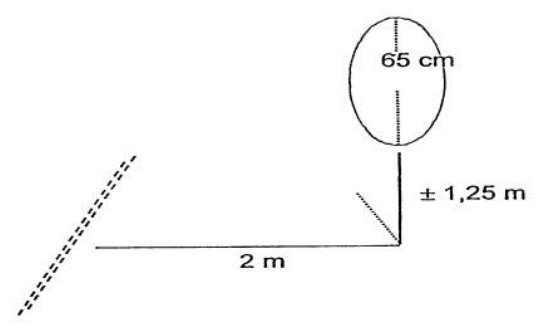

\section{Gambar 4. Tes Koordinasi Mata tangan Sumber : Winarno (2006:88)}

\section{Lompat Jauh Tanpa Awalan}

a. Tujuan. Tes ini bertujuan untuk mengukur kekuatan (power) otot tungkai.

b. Alat dan fasilitas

1) Alat tulis, 2) Meteran

c. Petugas Tes

1) Pengukur jarak, 2) Pencatat hasil

d. Pelaksanaan

1) Siswa mengambil posisi siap di belakang garis dengan dua kaki sejajar. Mengayunkan lengan kebelakang sambil menekuk lutut dan kemudian menolak dengan dua kaki kedepan sejauh mungkin.

2) Bekas tumit terdekat sampai garis di ukur dan di catat sebagai hasil lompatan.

3) Percobaan di lakukan tiga kali dan hasil lompatannya yang terjauh di catat sebagai hasil lompatan. Untuk lebih jelasnya dapat dilihat pada gambar di bawah ini:

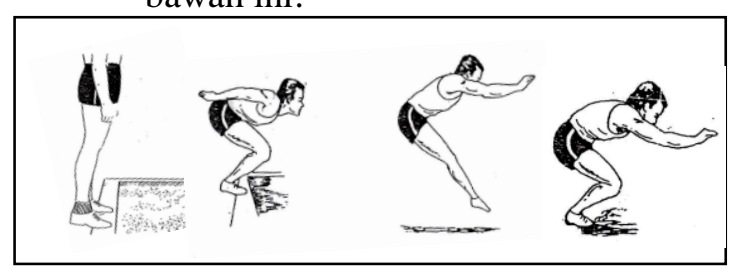

Gambar 5. Lompat Jauh Tampa Awalan Sumber : Lubis, ( 2004:37)

Tabel 3. Norma Tes Kemampuan Motorik

\begin{tabular}{|c|c|c|}
\hline No & Jumlah Nilai & Kategori \\
\hline 1 & $>14$ & Sangat Baik \\
2 & $12-13$ & Baik \\
3 & $10-11$ & Sedang \\
4 & $8-9$ & Kurang \\
5 & $<7$ & Sangat Kurang \\
\hline
\end{tabular}

Teknik analisis data yang digunakan statistik deskriptif yang menggunakan tabulasi frekuensi dengan rumus:

$$
P=\frac{F}{N} \times 100 \%
$$

\section{HASIL DAN PEMBAHASANA}

Variabel dalam penelitian ini adalah kemampuan motorik siswa Sekolah Dasar Negeri 
28 Air Tawar Timur Kecamatan Padang Utara Kota Padang. Variabel kemampuan motorik meliputi kemampuan lempar bola basket, lari cepat 40 Meter, passing bola ke dinding dan lompat jauh tanpa awalan. Deskripsi data hasil tes kemampuan motorik pada responden, secara distribusi frekuensi dapat digambarkan sebagai berikut ;

Tabel 4. Deskripsi Data Penelitian

\begin{tabular}{|c|c|c|c|c|c|c|}
\hline Variabel & $\begin{array}{c}\text { Dat } \\
\mathbf{a}\end{array}$ & $\mathbf{N}$ & $\begin{array}{c}\text { Me } \\
\text { an }\end{array}$ & $\begin{array}{c}\text { Std. } \\
\text { Dev }\end{array}$ & $\begin{array}{c}\text { Mi } \\
\mathbf{n}\end{array}$ & $\begin{array}{c}\text { Ma } \\
\mathbf{k}\end{array}$ \\
\hline \multirow{2}{*}{$\begin{array}{c}\text { Kemampua } \\
\text { n Motorik }\end{array}$} & $\begin{array}{c}\text { Putr } \\
\text { a }\end{array}$ & 16 & $\begin{array}{c}13.3 \\
8\end{array}$ & 0.89 & 12 & 15 \\
\cline { 2 - 7 } & $\begin{array}{c}\text { Putr } \\
\text { i }\end{array}$ & 19 & $\begin{array}{c}12.5 \\
8\end{array}$ & 1.46 & 10 & 16 \\
\hline
\end{tabular}

Jelasnya secara deskriptif dapat disajikan sebagai berikut ;

1. Putra

Hasil analisis kemampuan motorik siswa SD Negeri 28 Air Tawar Timur Kecamatan Padang Utara Kota Padang dengan jumlah responden 16 orang, diperoleh rerata hitung (mean) $=13.38$, standar deviasi $=0.89$, nilai minimum $=12$ dan maksimum $=15$.

Selanjutnya dalam deskripsi ini disajikan distribusi kemampuan motorik siswa dari responden penelitian yang sesuai norma tes kemampuan motorik untuk anak umur $10-12$ tahun sebagai berikut :

Tabel 5. Norma Tes Kemampuan Motorik

\begin{tabular}{|c|c|c|}
\hline No & Jumlah Nilai & Kategori \\
\hline 1 & $>14$ & Sangat Baik \\
2 & $12-13$ & Baik \\
3 & $10-11$ & Sedang \\
4 & $8-9$ & Kurang \\
5 & $<7$ & Sangat Kurang \\
\hline
\end{tabular}

Berdasarkan rentang nilai di atas, dapat digambarkan penyebaran distribusi frekuensi data penelitian sesuai tingkat klasifikasi masing-masing. Jelasnya dapat dilihat pada tabel berikut :

Tabel 6. Distribusi Frekuensi Kemampuan Motorik Putra

\begin{tabular}{|c|c|c|c|c|}
\hline No & Klafikasi & Nilai & $\mathbf{F a}$ & Fr \\
\hline 1 & $\begin{array}{l}\text { Sangat } \\
\text { Baik }\end{array}$ & $>14$ & 6 & 37.50 \\
\hline 2 & Baik & $\begin{array}{l}12- \\
13\end{array}$ & 10 & 62.50 \\
\hline \multicolumn{3}{|c|}{ Jumlah } & 16 & 100 \\
\hline
\end{tabular}

Untuk lebih jelasnya dapat digambarkan sebagai berikut :

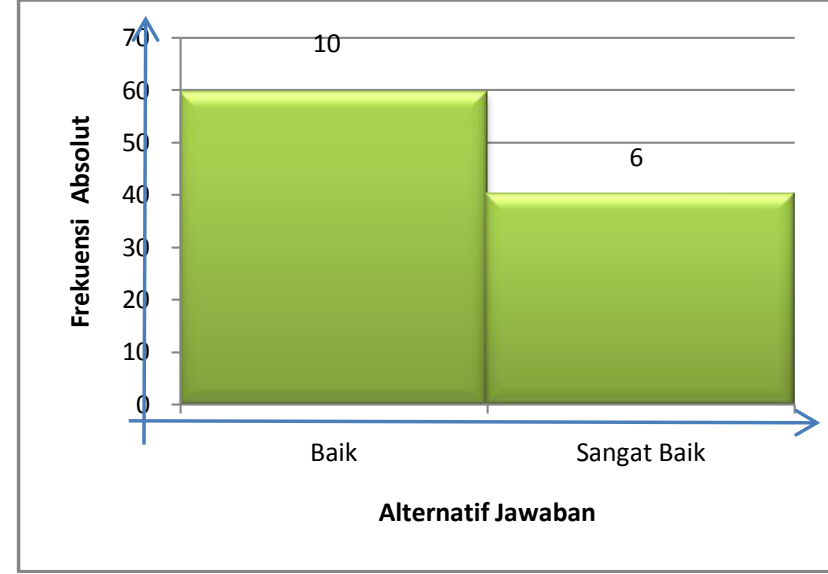

\section{Gambar 6. Histogram Frekuensi Kemampuan Motorik Putra}

\section{Putri}

Hasil analisis kemampuan motorik siswa SD Negeri 28 Air Tawar Timur Kecamatan Padang Utara Kota Padang dengan jumlah responden 19 orang, diperoleh rerata hitung (mean) $=12.58$, standar deviasi $=1.46$, nilai minimum $=10$ dan maksimum $=16$.

Selanjutnya dalam deskrinsi ini disajikan distribusi kemampuan motori 29 wa dari responden penelitian yang norma tes kemampuan motorik untuk anan unнui $10-12$ tahun sebagai berikut :

\section{Tabel 7. Distribusi Frekuensi Kemampuan} Motorik Putri

\begin{tabular}{|c|l|c|c|c|}
\hline No & Klafikasi & Nilai & Fa & Fr \\
\hline 1 & Sangat Baik & $>14$ & 4 & 21.05 \\
\hline 2 & Baik & $12-13$ & 11 & 57.89 \\
\hline 3 & Sedang & $10-11$ & 4 & 21.05 \\
\hline Jumlah & 19 & 100 & \multicolumn{2}{|c}{} \\
\cline { 1 - 3 } & &
\end{tabular}

Untuk lebih jelasnya dapat digambarkan sebagai berikut :

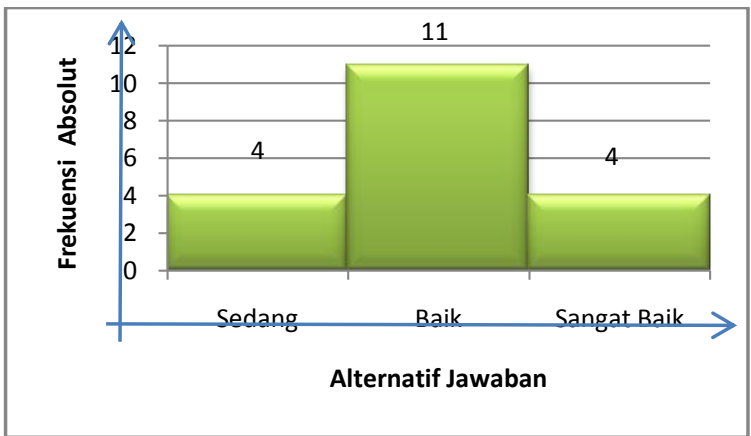

Gambar 7. Histogram Frekuensi

Kemampuan Motorik Putri

Jawaban Pertanyaan Penelitian

1. Seberapa Baikkah Kemampuan Motorik Siswa Putra Sekolah Dasar Negeri 28 air Tawar Timur Kecamatan Padang Utara Kota Padang. 
Sesuai data yang dikumpulkan dari 16 responden penelitian mewakili siswa putra diperoleh penyebaran jawaban berdasarkan tingkat klasifikasi sebagai berikut, kategori " sangat baik " sebanyak 6 orang atau $37.50 \%$, kategori "baik" sebanyak 10 orang atau $62.50 \%$ sedangkan kategori sedang, kurang dan sangat kurang tidak ada.

\section{Seberapa Baikkah Kemampuan Motorik} Siswa Putri Sekolah Dasar Negeri 28 air Tawar Timur Kecamatan Padang Utara Kota Padang.

Sesuai data yang dikumpulkan dari 16 responden penelitian mewakili siswa putri diperoleh penyebaran jawaban berdasarkan tingkat klasifikasi sebagai berikut, kategori " sangat baik " sebanyak 4 orang atau $21.50 \%$, kategori "baik" sebanyak 11 orang atau $57.89 \%$ dan kategori "sedang" sebanyak 4 orang atau $21.05 \%$ sedangkan kategori kurang dan sangat kurang tidak ada.

\section{Pembahasan}

Berdasarkan temuan penelitian yang telah diuraikan di atas, kemampuan motorik diartikan sebagai kecakapan dan kesanggupan siswa melakukan suatu gerak (motorik). Begitu juga halnya dengan siswa Sekolah Dasar 28 Air Tawar Timur Kecamatan Padang Utara Kota Padang, mereka sebaiknya memiliki kemampuan motorik yang baik agar bisa memiliki kemampuan fisik yang baik sehingga dapat bergerak lebih efektif dan efisien serta mampu mengontrol gerakan dalam bertindak.

Kemampuan motorik erat kaitannya dengan perkembangan pengetahuan siswa. Siswa mempelajari cara mengkoordinasi dan mengontrol tubuh mereka dengan bergerak dan menggunakan indrawi yang dihasilkan sebagai akibat dari tindakan. Pola gerakan yang selalu di ulang menghasilkan penguatan terhadap jalur syaraf yang mendukung pola gerakan. Sebagaimana yang dikemukakan (Kiram, 2000:5) bahwa kemampuan motorik adalah suatu peristiwa laten yang meliputi keseluruhan proses-proses pengendalian dan pengaturan fungsi-fungsi organ tubuh baik secara fisiologis maupun secara psikis yang menyebabkan terjadinya gerakan.

Dilain pihak juga dikemukakan bahwa kemampuan motorik merupakan kualitas kemampuan seseorang (individu) dalam melakukan gerakan yang dipandang sebagai landasan keberhasilan untuk menyelesaikan keterampilan gerak.

Dengan demikian dapat dikatakan seseorang yang memiliki kemampuan motorik yang tinggi, diduga akan lebih berhasil dalam menyelesaikan tugas keterampilan motorik khusus. Karena kemampuan $n$ kualitas kemampuan seseor mempermudah dalam melakı 31 nerupakan ng dapat terampilan gerak.

Hal senada juga dikemukakan Ulrich dalam Syahrial Bachtiar (2000) bahwa perkembangan gerakan sebagai "peralihan dalam tingkah laku selama kehidupan dan prosesproses yang mendasari peralihan itu. Lebih lanjut dapat didefinisikan bahwa "keterampilan gerak yang melibatkan keterampilan otot besar, kekuatan otot tubuh, lengan dan kaki, yang di gunakan untuk mencapai sebuah latihan atau tujuan gerakan seperti melempar sebuah bola kepada teman, perkembangan gerak dasar mencakup pembangunan perilaku gerak yang di gunakan untuk memindahkan tubuh dari satu tempat ke tempat lain.

Untuk itu berdasarkan pengertian diatas, dalam penelitian ini kemampuan motorik siswa diukur menggunakan beberapa tes motorik yaitu kemampuan lempar bola basket, lari 40 meter, passing bola ke dinding dan lompat jauh tanpa awalan. Pada dasarnya kemampuan motorik seseorang dipengaruhi oleh aktivitas fisik dan olahraga yang dilakukan sehari-hari. Sebagaimana yang dikemukakan Gusril (2003:9) bahwa faktor yang mempengaruhi kemampuan motorik seseorang adalah kesegaran jasmani, aktivitas bermain dan status gizi.

Dengan demikian dapat dikatakan semakin baik aktivitas fisik yang dilakukan seseorang maka semakin baik pula tingkat kemampuan motoriknya. Dari hasil analisis deskriptif data penelitian diketahui bahwa dari 16 responden putra menunjukkan bahwa kemampuan motorik siswa SD Negeri 28Air Tawar Timur Kecamatan Padang Utara Kota Padang menurut masing-masing tes kemampuan motorik diketahui bahwa kemampuan motorik kategori "Sangat Baik" 6 orang "Baik" 10 orang, sedangkan kategori "Sedang", "Kurang" dan "Sangat Kurang" tidak ada.

Selanjutnya dari 19 responden putri menunjukkan bahwa kemampuan motorik siswa SD Negeri 28Air Tawar Timur Kecamatan Padang Utara Kota Padang menurut masingmasing tes kemampuan motorik diketahui bahwa kemampuan motorik kategori "Sangat Baik" frekuensi 4 orang, "Baik" 11 orang, "Sedang" 4 orang, sedangkan kategori "Kurang" dan "Sangat Kurang" tidak ada. 
Berpedoman pada hasil studi kemampuan motorik siswa Sekolah Dasar Negeri 28 Air Tawar Timur Kecamatan Padang Utara Kota Padang dapat dikatakan bahwa secara keseluruhan kemampuan motorik siswa baik putra maupun putri berada pada kategori baik.

Hal ini dibuktikan dari persentase kemampuan motorik pada umumnya (terbesar) adalah sebesar $62.50 \%$ untuk putra dan $57.89 \%$ untuk putri pada kategori baik. Ada banyak faktor yang menyebabkan hal ini terjadi seperti komponen kesehatan. Komponen ini terdiri dari empat hal pokok yaitu daya tahan cardio vascular, daya tahan dan kekuatan otot, keseimbangan pertumbuhan tubuh serta kelentukan. Selanjutnya komponen keterampilan yang terdiri dari daya tahan, kekuatan otot, tenaga ledak otot, kecepatan dan ketangkasan.

Hal ini dikuatkan oleh pendapat Bowers dalam Arsil (2008) yang menyatakan bahwa "daya tahan merupakan salah satu komponen biomotorik yang sangat dibutuhkan dalam aktivitas fisik, dan salah satu komponen terpenting dari kesegaran jasmani”.

Kutipan ini menjelaskan bahwa seseorang yang memiliki daya tahan tubuh yang tinggi, maka kondisi tubuhnya akan mampu bekerja dalam waktu yang lama tanpa mengalami kelelahan yang berarti atau berlebihan. Semua komponen ini sangat diperlukan pada semua aktivitas fisik seseorang, termasuk siswa sekolah dasar.

Merujuk pada hasil penelitian yang menyatakan bahwa kemampuan motorik siswa umumnya pada kategori baik, maka dapat disimpulkan bahwa komponen-komponen kesegaran jasmani, aktivias bermain dan status gizi sangat mempengaruhi kemampuan motorik siswa SD Negeri 28Air Tawar Timur Kecamatan Padang Utara Kota Padang dalam bertindak dan pengembangan pengetahuan. Kemampuan motorik ini dapat ditingkatkan melalui latihan-latihan olahraga dan aktivitas bermain yang sering dilakukan oleh anak-anak seusia Sekolah Dasar. Untuk itu perlu suatu program orientasi pengembangan dan pelatihan motorik bagi seseorang, khususnya bagi siswa Sekolah Dasar Negeri 28Air Tawar Timur Kecamtan Padang Utara Kota Padang.

\section{Kesimpulan}

Berdasarkan hasil penelitian tentang tinjauan kemampuan motorik siswa Sekolah Dasar Negeri 28 Air Tawar Timur Kecamatan Padang Utara Kota Padang, ditemukan beberapa orang siswa yang mempunyai kemampuan motorik kurang dan kurang sekali.

Untuk itu disarankan kepada; Guru Penjasorkes dalam pembelajaran Penjasorkes agar lebih banyak memberikan kegiatan belajar dalam bentuk bermain, karen $c^{\prime} \cdot{ }^{\prime} \cdot{ }^{\prime}$ is bermain dapat meningkatkan kemampu 34 rik siswa

Siswa agar dapat mem an faktorfaktor yang mempengaruhı Kemampuan motorik. Orang tua atau wali murid agar lebih memperhatikan makanan atau kebutuhan gizi anaknya, sehingga dapat meningkatkan kemampuan motorik mereka.

Kepada para peneliti lainnya diharapkan dapat mengembangkan penelitian ini dengan jumlah sampel yang lebih banyak atau variabel lain yang belum diteliti.

\section{DAFTAR PUSTAKA}

Arikunto, Sumarsimi. 2002. Manajemen penelitian. Jakarta. Depdikbud.

Arsil. 2009. Tes Pengukuran dan Evaluasi. Padang: Sukabina. FIK. UNP

Depdiknas. 2003. Dasar-dasar Kepelatihan Olahraga. Jakarta. Proyek Pendidikan Jasmani Luar biasa

Gusril. 2003. Faktor-Faktor Yang Mempengaruhi Kemampuan Motorik Siswa Sekolah Dasar Negeri Kodya Padang. Disertasi. Jakarta : Pascasarjana. UNP

2008. Model Pengembangan Motorik Pada Siswa Sekolah Dasar. Padang: UNP Press.

Kiram, Yanuar. 2000. Belajar Motorik. Padang: FIK- UNP.

Lutan, Rusli. 2002. Mengajar Untuk Belajar Dalam pendidikan Jasmani, Bandung : FPOK Universitas Pendidikan Indonesia

Lubis, Johansyah. 2004. Instrumen Pemanduan Bakat Pencak Silat Direktorat Pelajar dan Mahasiswa. Jakarta; Ditjen Dikti Depdiknas. 
Mutohir, T.Cholik dkk. 2004. Perkembangan Motorik Pada Masa Anak-anak. Jakarta: PPKKO, Dirjen Olahraga, Depdiknas.

Muhajir. 2006. Pendidikan Jasmani Olahraga dan Kesehatan. Jakarta : Erlangga

Sudjana. 1989. Metode Statistik. Bandung : Transito .,1992. Metode Statistik (edisike - 5).

Bandung : Transito.

Sukintaka, 2004. Teori Pendidikan Jasmani: Filosofi Pembelajaran Dan Masa Depan. Bandung: Nuansa.

UNP. 2010. Buku Pedoman Penulisan Skripsi/TA. Padang. UNP.

Winarno. 2006. Tes Keterampilan Olahraga. Malang: Laboratoriun Jurusan Ilmu Keolahragaan. FIP. UNM. 